\title{
PRODUCTION AND NUTRIENT CONTENT OF TWO SHRUB SPECIES RELATED TO FIRE IN CENTRAL IDAHO
}

\author{
James M. Peek ${ }^{1}$
}

\begin{abstract}
Nutrient content and weight of current year's growth of Cercocarpus ledifolius Nuttall and Physocarpus malvaceus (Greene) Kuntze in central Idaho were obtained during early July in the years 1987-2007. The purpose of this work was to determine whether there was significant variation between years and whether mean monthly temperatures and total monthly precipitation could predict the variation. A wildfire in August 2000 caused P. malvaceus to vigorously resprout. Significant differences between years occurred for all nutrients for both species. October temperatures best predicted weight of current year's growth in C. ledifolius, whereas prediction equations for nutrients involved spring temperatures and precipitation, primarily for June. January mean temperature and December precipitation best predicted weight of current year's growth, and spring mean monthly temperatures best predicted nutrient levels in P. malvaceus. Future changes in production and nutrient content of these species that are not predicted may be related to climate change.
\end{abstract}

Resumen.-El contenido de nutrientes y el aumento de peso anual de Cercocarpus ledifolius Nuttall y Physocarpus malvaceus (Greene) Kuntze en la zona central de Idaho, fueron monitoreados desde principios de julio, entre 1987 y 2007. El propósito de este trabajo fue determinar si existieron variaciones significativas entre años y si las temperaturas promedio mensuales y las precipitaciones mensuales totales podrían predecir algún tipo de variación. Un incendio en agosto del año 2000 causó que P. malvaceus rebrotara vigorosamente. Encontramos diferencias significativas entre años en todos los nutrientes para ambas especies. Las temperaturas de octubre predijeron mejor el aumento de peso anual en C. ledifolius, mientras que las ecuaciones de predicción de nutrientes involucraron temperaturas de primavera y la precipitación, principalmente en junio. La temperatura promedio de enero y la precipitación de diciembre predijeron con mayor exactitud el aumento de peso anual y la temperatura promedio mensual de primavera predijo con mayor exactitud los niveles de nutrientes en P. malvaceus. Los futuros cambios en la producción y el contenido de nutrientes de estas especies que no fueron predichas podrían estar relacionados con el cambio climático.

Forest and steppe communities in central Idaho contain a mix of resprouting and nonresprouting species, indicating a mix of evolutionary history. Nonresprouting species include Artemisia tridentata vaseyana (Rydb.) Beetle, Cercocarpus ledifolius Nuttall, and Purshia tridentata (Pursh) DC, a weak or nonsprouter. These species all likely evolved with relatively low disturbance frequencies where adaptation to fire is mainly through seed dispersal (Wing 1987, Bellingham and Sparrow 2000, Pausas 2001). Purshia tridentata and C. ledifolius are considered part of the Madro-Tertiary geoflora, originating in southwestern North America (McArthur et al. 1983, Wing 1987).

Sprouting species in this region commonly include Physocarpus malvaceus (Greene) Kuntze and Symphoricarpos albus (L.) Blake, which likely originated in regions of higher disturbance where adaptation was influenced by more frequent fires (Pausas 2001, Altwegg et al. 2015). Physocarpus spp. have a postu- lated origin in eastern Asia. They occured in Arctic North America in the late Tertiary (Matthews and Ovenden 1990) and close relatives dated to the middle Eocene were located in temperate forest at Republic, Washington (Wolfe and Wehr 1991). Symphoricarpos was well represented in the northern Great Basin flora by the late Pleistocene (Nowak et al. 1994) and the genus is currently widely distributed across North America (Hitchcock and Cronquist 1996). Flora of this region thus represent a combination of differently evolving species, which likely ebb and flow depending upon local fluctuations of climate plus frequency and severity of fires. Shrubs may be among the first plants to respond to increased atmospheric $\mathrm{CO}_{2}$ since they metabolize $\mathrm{CO}_{2}$ more readily than associated grasses do (Mayeux et al. 1991, Polley et al. 1994, Manea and Leishman 2015).

Ecological investigations of C. ledifolius mainly describe soil and habitat relationships

${ }^{1}$ Department of Fish and Wildlife Sciences, University of Idaho, Moscow, ID 83844-1136. E-mail: peek@uidaho.edu 


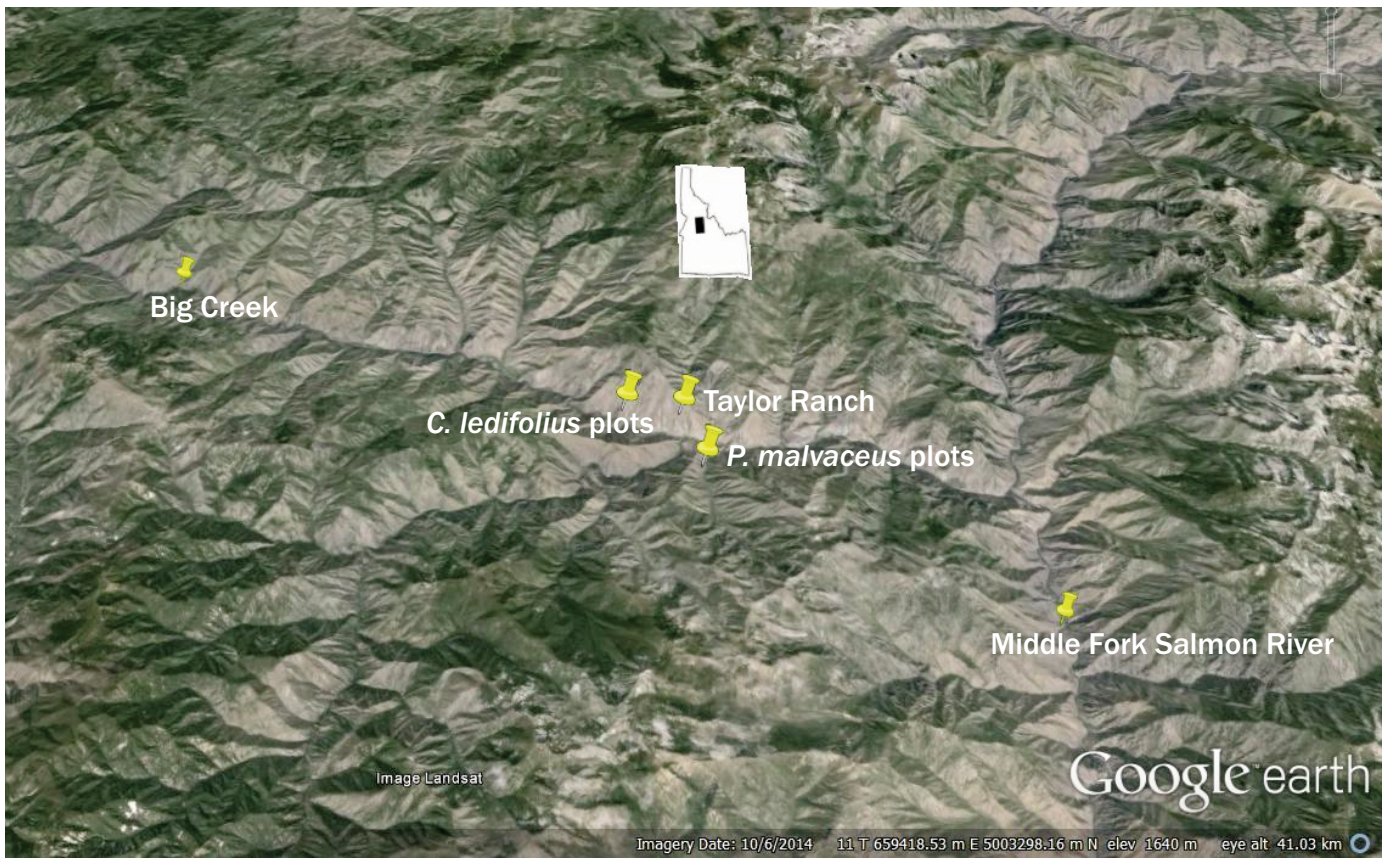

Fig. 1. Map of lower Big Creek drainage showing location of study sites in relation to the Taylor Ranch facility and Middle Fork of the Salmon River, Idaho. Image: Landsat.

(Scheldt and Tisdale 1970, Davis and Brotherson 1991), as well as seedling establishment and survival (Dealy 1978, Schultz et al. 1996, Russell and Schupp 1998). Efforts to regenerate decadent stands of $C$. ledifolius have been described, because it is so highly palatable. Investigations of $P$. malvaceus, which often increases to dense stands that hinder conifer seedling development following removal of the tree overstory, mainly involve evaluation of treatments to reduce cover values for forest management applications (Steele et al. 1981).

This work describes variation in nutrient content and weight of current year's growth of C. ledifolius and P. malvaceus, important shrubs in central Idaho. Cercocarpus ledifolius is a major forage species for native ungulates, occurring from southeast Washington to California and Arizona, east to Montana and Colorado. Physocarpus malvaceus is a common shrub in dry forests from southern Alberta and British Columbia to Wyoming and Utah (Hitchcock and Cronquist 1996).

An additional goal was to develop predictions of nutrient content and production using monthly mean temperature and total monthly precipitation records. Predictions for produc- tion cover a 20-year period which included a wildfire in August 2000 that burned the P. malvaceus stand, allowing examination of responses of this species to the fire. Nutrient content was predicted for a 10-year period at one phenological stage of annual plant growth. Single stands of each species are reported. Sites selected for study were considered representative of sites within the Salmon River drainage.

\section{Methods}

\section{Study Area}

The study occurred in the Big Creek drainage, a major tributary to the Middle Fork of the Salmon River in central Idaho $\left(115^{\circ} 00^{\prime}\right.$ W, $45^{\circ} 15^{\prime} \mathrm{N}$; Fig. 1). This area lies within the Frank Church River-Of-No-Return Wilderness. The geology of this area is complex, but consists primarily of granites and granodiorites with some rhyolites (Bond et al. 1978). Elevations range from $1170 \mathrm{~m}$ above sea level at Taylor Ranch on Big Creek to $>2500 \mathrm{~m}$ at highest elevations. Shrubsteppe is dominated by A. tridentata vaseyana, C. ledifolius, and P. tridentata, with Pseudoroegneria spicata (Pursh) A. Love at lower elevations and Festuca 


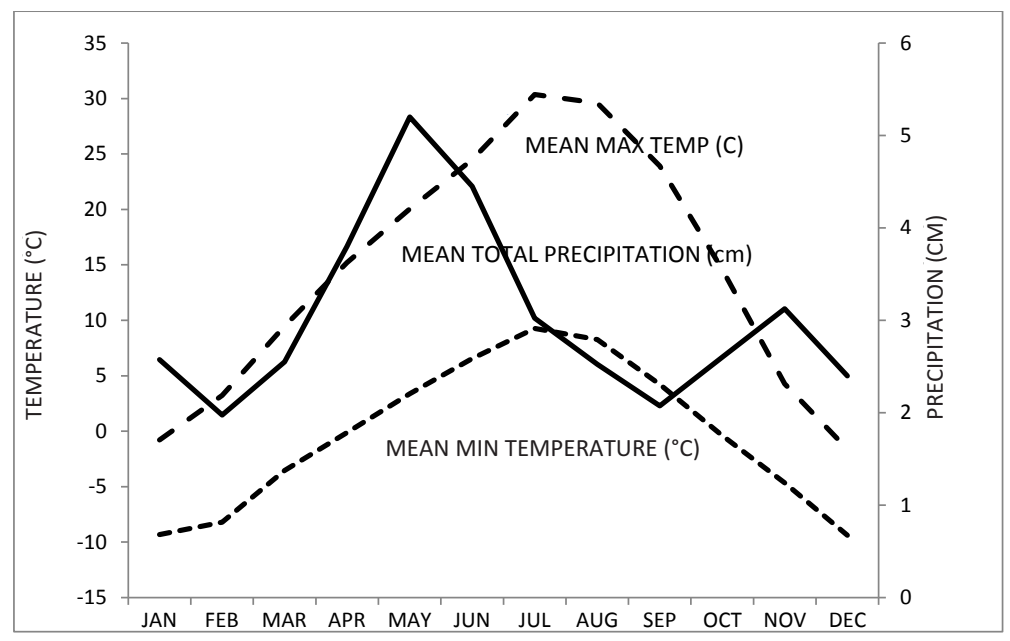

Fig. 2. Mean maximum and minimum monthly temperatures, and mean total monthly precipitation, Taylor Ranch, Idaho, 1974-2005.

idahoensis Elmer at higher elevations (Peek et al. 2005). Pseudotsuga menziesii (Mirbel) Franco and Pinus ponderosa Douglas stands are present as sparse tree cover on southfacing aspects and as closed-canopy forest on more northerly aspects (Steele et al. 1981). Symphoricarpos albus and P. malvaceus commonly occur as understory plants in these stands.

Mean annual precipitation at Taylor Ranch, located $<1 \mathrm{~km}$ from all sites was $35.5 \mathrm{~cm}$ over the 1974-2005 period (Fig. 2; Western Regional Climate Center 2011). Highest precipitation occurred usually as snow in January. Monthly precipitation values for April-June are the next highest, and July-September precipitation is the lowest for the year. Temperatures at Taylor Ranch ranged from $-0.4{ }^{\circ} \mathrm{C}$ to $-9.9{ }^{\circ} \mathrm{C}$ (average $-4.7{ }^{\circ} \mathrm{C}$ ) in January and December and from $17.0^{\circ} \mathrm{C}$ to $25.0{ }^{\circ} \mathrm{C}(\bar{x}=$ $18.9{ }^{\circ} \mathrm{C}$ ) in July. Precipitation in OctoberJune, the months of growing season affecting the measurements, averaged $29.57 \mathrm{~cm}$, with a low for the study occurring in $1990(21.88 \mathrm{~cm})$ and a high in $1999(41.66 \mathrm{~cm})$.

The C. ledifolius stand occurred on a steep south-facing cliff approximately $200 \mathrm{~m}$ above the river. This stand classifies as a C. ledifolius / P. spicata community (Peek et al. 2005). Soils on this site were rocky and mostly $<50 \mathrm{~cm}$ deep, with root systems penetrating cracks in underlying substrate. A calculated N:P ratio of 0.20:1.00 for C. ledifolius twigs suggests that this stand is severely nitrogen limited (Aerts and Chapin 2000). The 2000 fire burned irregularly across this cliff with 5 plants along the transect left intact. Bare rock and soils typical of cliffy sites usually produce irregularly distributed burns (Clarke 2002), and sufficient plants were left unburned to continue the study following the fire.

The $P$. malvaceus stand occurred initially as an understory beneath a mature stand of Pseudotsuga menziesii (density $=51$ trees ${ }^{\circ}$ $\mathrm{ha}^{-1}$ ) on a gently north-facing drainage of $<10^{\circ}$ slope. This stand classifies as a P. menziesii/P. malvaceus habitat type (Steele et al. 1981). Soils on this site were composed of sandy alluvium, which was very rocky and highly variable in depth. The site was severely burned in August 2000, with the crown fire killing all trees. Heavy accumulation of ash on the site was observed in September after the fire was out, and P. menziesii root systems extending up to $1 \mathrm{~m}$ into the ground had been completely eliminated. The calculated N:P ratio of 0.35:1.00 for $P$. malvaceus indicates severe nitrogen limitation (Aerts and Chapin 2000). Shrubs in this stand were densely distributed compared to the sparsely and irregularly distributed plants in the C. ledifolius stand.

\section{Measurements}

Weight of current year's growth (twigs and leaves on twigs) provides a minimum estimate of aboveground annual production because 
growth of older tissue is not included. Nutrient content of current year's growth is also reported. The burn enabled evaluation of $P$. malvaceus resprouting response 12 years prior to and 7 years after the fire. The $C$. ledifolius stand examined was partially burned, allowing continued collection of current year's growth of unburned plants over the entire study period. Methods of twig weight and nutrient level prediction use commonly available monthly precipitation and temperature values as predictors.

Plant heights, number of rooted stems, current year's twig growth (hereafter designated twigs), twig length, and twig weight (including leaves attached to twigs) were obtained for each species from 1988 to 2007. Plots were established from a randomly selected point near the center of each stand and were $3 \mathrm{~m}$ apart. Stems and twigs were counted in twenty $4-\mathrm{m}^{2}$ circular plots (1.13-m radius). The $4-\mathrm{m}^{2}$ circular plot was visualized as a cylinder and each twig that occurred within that cylinder was counted. Up to 5 twigs from plants located adjacent to the plots were selected for clipping. Plants selected for sampling were visually separated into 3 levels, and at least 1 twig was collected from each level. Fifty twigs of each species were cut, weighed while still wet, stored, and then weighed after being oven-dried at $40{ }^{\circ} \mathrm{C}$ for $24 \mathrm{~h}$. Twigs were cut in early July after growth had concluded for the year. Only twigs without flower stalks were collected. Study sites were identified with a stake, and a different direction was taken each year for twig collections.

Nutrient content was determined for twigs collected from 1997 to 2007 . The purpose of these collections was to test the null hypothesis that no changes in nutrient content of plants at maturity could be detected between years. Nutrient content was determined using Leeman 2000 or Perkin Elmer Optima 3200 RL instrumentation at the Analytical Sciences Laboratory at the University of Idaho.

\section{Analysis}

Plot sizes and numbers were evaluated for a Purshia tridentata and a P. malvaceus stand. Methods described above were used for this analysis. Circular plots subscribing 1, 2, and $4 \mathrm{~m}^{2}$ were randomly located. Rooted stem densities and numbers of twigs within the visually circumscribed cylinder above the plot were counted in 84 plots of each size. Sample sizes of 20,30 , and 50 plots were analyzed in SAS with 100 iterations each in a bootstrap procedure.

Proc ANOVA (SAS 2008) was used to examine differences in number of stems, number of twigs, twig lengths, and twig weights on year for each species. Regression models were examined for their efficacy to predict twig weight and nutrient levels from monthly temperature and precipitation using Proc REG (SAS 2008) with Mallows's $C_{p}$ statistic (Mallows 1973). This statistic is a measure of total squared error:

$$
C_{p}=\frac{\mathrm{SSE}_{p}}{S^{2}}-N+2 p,
$$

where $S^{2}$ is the mean squared error for the model and $\mathrm{SSE}_{p}$ is the sum-of-squares error for a model with $p$ parameters including the intercept, if any (SAS 2008). Since models included monthly precipitation and temperatures for the year, the potential for overfitting was recognized and model choice was based on knowledge of potential regressors as well as the $C_{p}$ value closest to the number of predictive values in the regression (Gilmour 1996). Regressions presented were the best fit, and could be justified biologically. Transformations evaluated included log values for biomass and nutrients. A paired $t$ test was used to determine differences between the 1988-2000 period prior to the fire and for the 2003-2007 period following the fire in mean twig length, twig weight, stems, and twigs for P. malvaceus.

\section{RESUlTS}

\section{Plot Sizes and Numbers}

No significant differences in rooted stem or twig densities were observed relative to number of plots in either stand (Table 1). Plots of 1 $\mathrm{m}^{2}$ produced lower twig densities and lower standard deviations than the $2-\mathrm{m}^{2}$ and $4-\mathrm{m}^{2}$ plots in both stands. Stem density estimations were virtually equivalent for the 2 larger plot sizes in the $P$. malvaceus stand. Mean twig densities were lower and more variable in the C. ledifolius stand than in the P. malvaceus stand. Twenty $4-\mathrm{m}^{2}$ circular plots $(1.13-\mathrm{m}$ radius) were considered sufficient to estimate densities of stems and twigs in these stands, recognizing that the greater variability of the 
TABLE 1. Means and standard deviations (in parentheses) describing Physocarpus malvaceus and Cercocarpus ledifolius stands related to plot and sample sizes. Data are results of 100 iterations for each plot size and number based on a bootstrap analysis.

\begin{tabular}{|c|c|c|c|c|c|}
\hline \multirow[b]{2}{*}{ Number of plots } & \multirow[b]{2}{*}{ Plot size } & \multicolumn{2}{|c|}{ P. malvaceus } & \multicolumn{2}{|c|}{ C. ledifolius } \\
\hline & & Stems $\cdot \mathrm{m}^{-2}$ & Twigs $\cdot \mathrm{m}^{-2}$ & Stems $\cdot \mathrm{m}^{-2}$ & Twigs $\cdot \mathrm{m}^{-2}$ \\
\hline \multirow[t]{3}{*}{20} & $1 \mathrm{~m}^{2}$ & $3.4(3.72)$ & $21.3(20.10)$ & $0.37(0.84)$ & $16.37(36.99)$ \\
\hline & $2 \mathrm{~m}^{2}$ & $4.0(4.17)$ & $26.8(19.86)$ & $0.17(0.64)$ & $17.35(29.73)$ \\
\hline & $4 \mathrm{~m}^{2}$ & $4.0(4.19)$ & $27.7(18.38)$ & $0.42(0.90)$ & $30.37(47.52)$ \\
\hline \multirow[t]{3}{*}{30} & $1 \mathrm{~m}^{2}$ & $3.2(3.53)$ & $21.0(20.66)$ & $0.36(0.83)$ & $10.22(21.78)$ \\
\hline & $2 \mathrm{~m}^{2}$ & $3.9(4.52)$ & $26.6(20.20)$ & $0.16(0.64)$ & $29.50(38.55)$ \\
\hline & $4 \mathrm{~m}^{2}$ & $3.9(4.62)$ & $27.0(18.74)$ & $0.41(0.89)$ & $23.00(26.37)$ \\
\hline \multirow[t]{3}{*}{50} & $1 \mathrm{~m}^{2}$ & $3.3(3.79)$ & $22.4(21.19)$ & $0.36(0.83)$ & $16.47(36.61)$ \\
\hline & $2 \mathrm{~m}^{2}$ & $4.0(4.52)$ & $27.1(21.42)$ & $0.16(0.66)$ & $13.70(29.55)$ \\
\hline & $4 \mathrm{~m}^{2}$ & $3.9(4.47)$ & $27.8(19.30)$ & $0.46(0.89)$ & $29.87(47.25)$ \\
\hline
\end{tabular}

C. ledifolius stand would produce less reliable density information than for the $P$. malvaceus stand.

\section{Annual Stem and Twig Production}

Cercocarpus ledifolius stem densities averaged $0.09 \mathrm{stems} \cdot \mathrm{m}^{-2}$ (SD 0.19) without significant change attributable to the fire or year (Table 2; ANOVA: $F=0.12, P=0.73$ ). Plant heights averaged $90.21 \mathrm{~cm}$ (SD 38.01), with mean height prior to the fire of $104.49 \mathrm{~cm}$ (SD 32.41) and mean height following the fire of $58.80 \mathrm{~cm}$ (SD 16.38). The reduction in mean height following the fire was significant (ANOVA: $F=5.05, P=0.04$ ), with a few seedlings being established and then being progressively grazed and disappearing. Twig weights averaged $0.27 \mathrm{~g}$ (SD 0.14; range 0.19 0.52 ) over the 20 -year period without significant changes between years (ANOVA: $F=$ $0.19, P=0.12$ ). Twig biomass averaged 18.27 $\mathrm{kg} \cdot \mathrm{ha}^{-1}$ (range 5.2-43.7) over the 20-year period. Mean October temperature best predicted twig weight on this site (Fig. 3). Establishment of seedlings on burned sites after the fire occurred on this cliff, but seedlings were subject to browsing which otherwise was light on the site.

The P. malvaceus stand was exposed to a crown fire that completely burned the $P$. menziesii overstory. Rooted P. malvaceus stem densities increased from $2.68 \mathrm{stems} \cdot \mathrm{m}^{-2}$ (SD 1.50) prior to the 2000 fire to 3.85 stems $\cdot \mathrm{m}^{-2}$ (SD 0.15) for 7 years following the fire (Table 3). No significant differences in stem densities occurred between years prior to the fire, as expected. Stem densities for the 1988-2007 period increased (ANOVA: $F=10.23, P=$ 0.0001 ), indicating that the fire stimulated stem production. Stem heights declined from a mean of $115.6 \mathrm{~cm}$ (SD 15.5) from 1988 to 2000 to a mean of $81.5 \mathrm{~cm}$ (SD 2.8) from 2002 to 2007, with significant differences between years (ANOVA: $F=76.08, P=0.0001$ ). Mean stem height the year following the fire was $36.4 \mathrm{~cm}$, equivalent to current year's growth for that year. Sprouts were observed following the first rain after the fire in September 2000. No browsing of $P$. malvaceus was evident.

Twig densities changed over the entire 1988-2007 period $(F=29.26, P=0.0001)$. Twig density declined from a mean of 47.28 twigs $\cdot \mathrm{m}^{-2}$ (SD 23.82) from 1988 to 2000 prior to the fire to a mean of 27.40 twigs $\cdot \mathrm{m}^{-2}$ (SD 0.95) from 2002 to 2007 after the fire (Fig. 4). Mean twig length prior to the fire was $9.20 \mathrm{~cm}$ (SD 7.04; range 5.1-21.6). Twig length increased to $36.4 \mathrm{~cm}$ the year following the fire, $32.9 \mathrm{~cm}$ the second year after the fire, and $11.3 \mathrm{~cm}$ the third and fourth years following the fire. Twig length then averaged $7.38 \mathrm{~cm}$ (SD 4.49; range 4.55-11.5) for 2004-2007. Excluding the first 2 years following the fire, no significant differences in twig lengths were observed $(t=2.01, P=0.082)$. Twig weight did increase significantly following the fire (ln weight, $t=2.52, P=0.045)$. Mean twig weight was $0.33 \mathrm{~g}$ (SD 0.36; range 0.16-0.89) prior to the fire, increased to $2.62 \mathrm{~g}$ the year following the fire, then $1.88 \mathrm{~g}$ the second year, and $1.6 \mathrm{~g}$ the third year after the fire. Twig weights then averaged $0.33 \mathrm{~g}$ (SD 0.20; range $0.20-0.52)$ from 2004 to 2007 . Total twig biomass averaged $160.9 \mathrm{~kg} \cdot \mathrm{ha}^{-1}$ (range 20.1$368.5)$ from 1988 to 2000 and $140.1 \mathrm{~kg} \cdot \mathrm{ha}^{-1}$ (range 55.2-298.6) in 2002-2007. January mean temperature and December precipitation best predicted twig weight (Fig. 3). The 


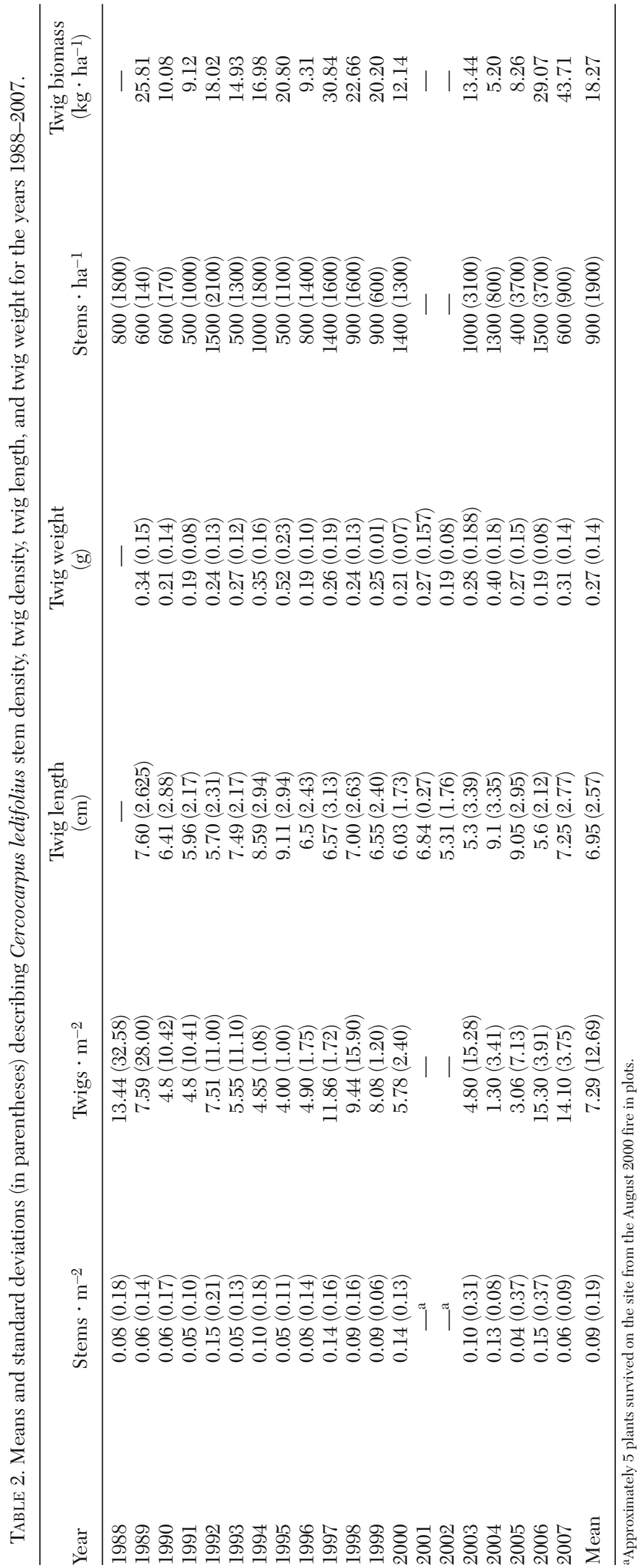




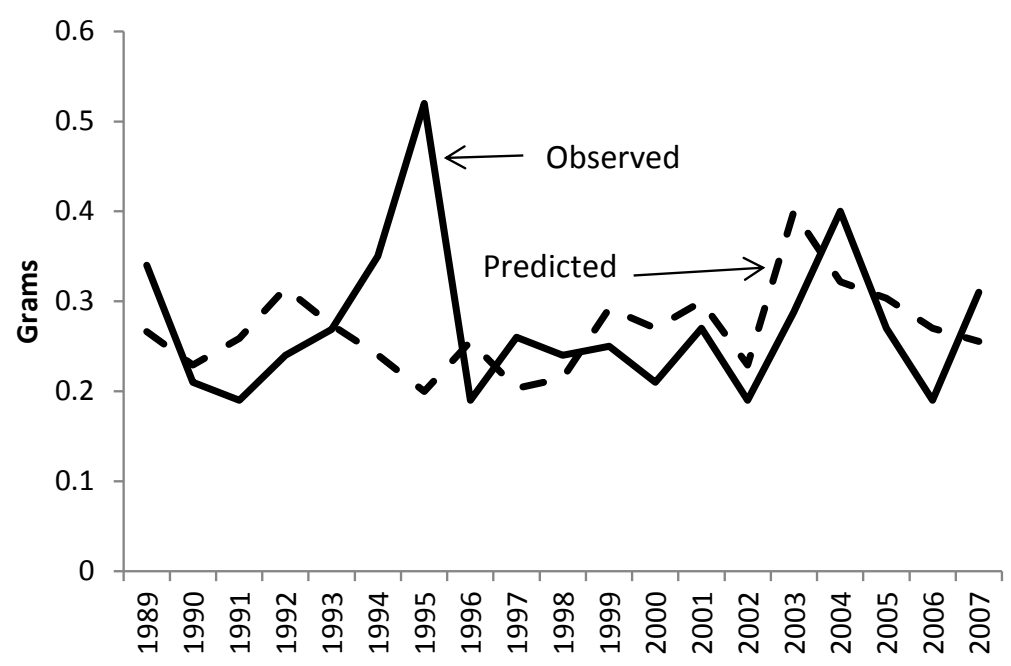

Fig. 3. Observed and predicted annual twig weights in Cercocarpus ledifolius. Prediction: $\mathrm{g} \cdot \mathrm{twig}^{-1}=0.037$ OCTT $\left(F=128.09, P<0.0001, C_{p}=0.25\right)$, where OCTT is mean October temperature.

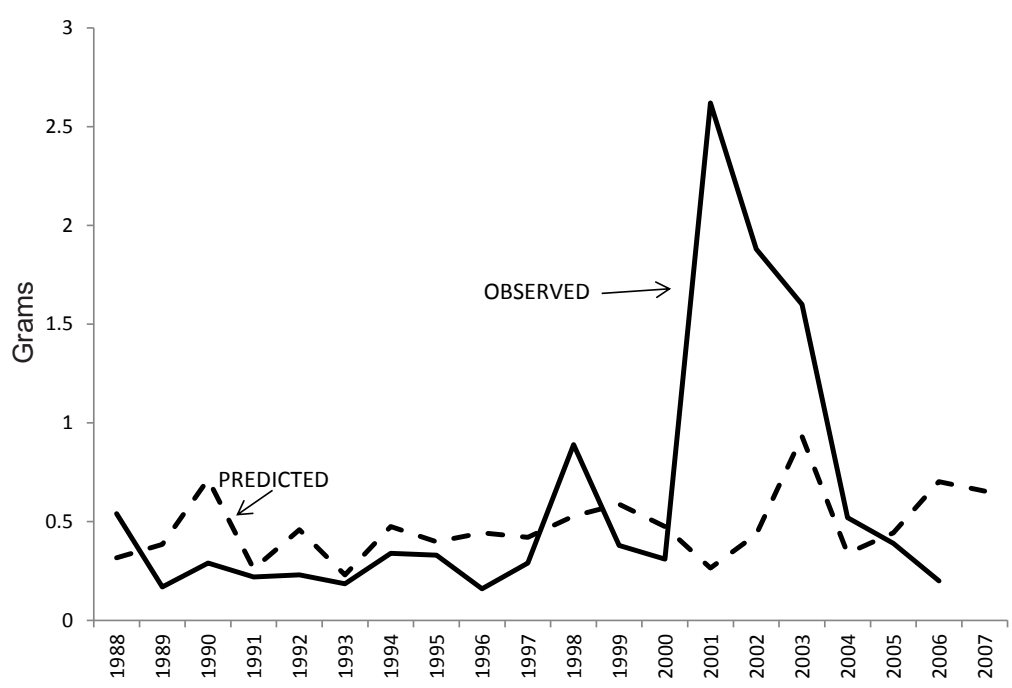

Fig. 4. Observed and predicted annual twig weights in Physocarpus malvaceus. Prediction: $\mathrm{g} \cdot \mathrm{twig}^{-1}=0.177 \mathrm{JANT}-$ $0.112 \mathrm{DECP}\left(F=35.21, P=0.0001, C_{p}=2.00\right)$, where JANT is mean January temperature and DECP is total December precipitation.

high observed values of twig weight for 3 years following the fires were much greater than the predicted values and were attributable to the post-fire growth.

\section{Nutrients}

Samples of C. ledifolius and P. malvaceus for determination of nutrient content were collected during 1998-2007 (Table 4). For both species, significant differences between years occurred for all nutrients. Seven of the 9 predictions for C. ledifolius nutrients included total June precipitation and mean June temperature (Table 4). Predictions for Fe included March and April mean temperature, whereas Zn was negatively correlated with April temperature and April precipitation. Levels of $\mathrm{Ca}$ at $7570 \mu \mathrm{g} \cdot \mathrm{g}^{-1}$ were highest of the nutrients, 


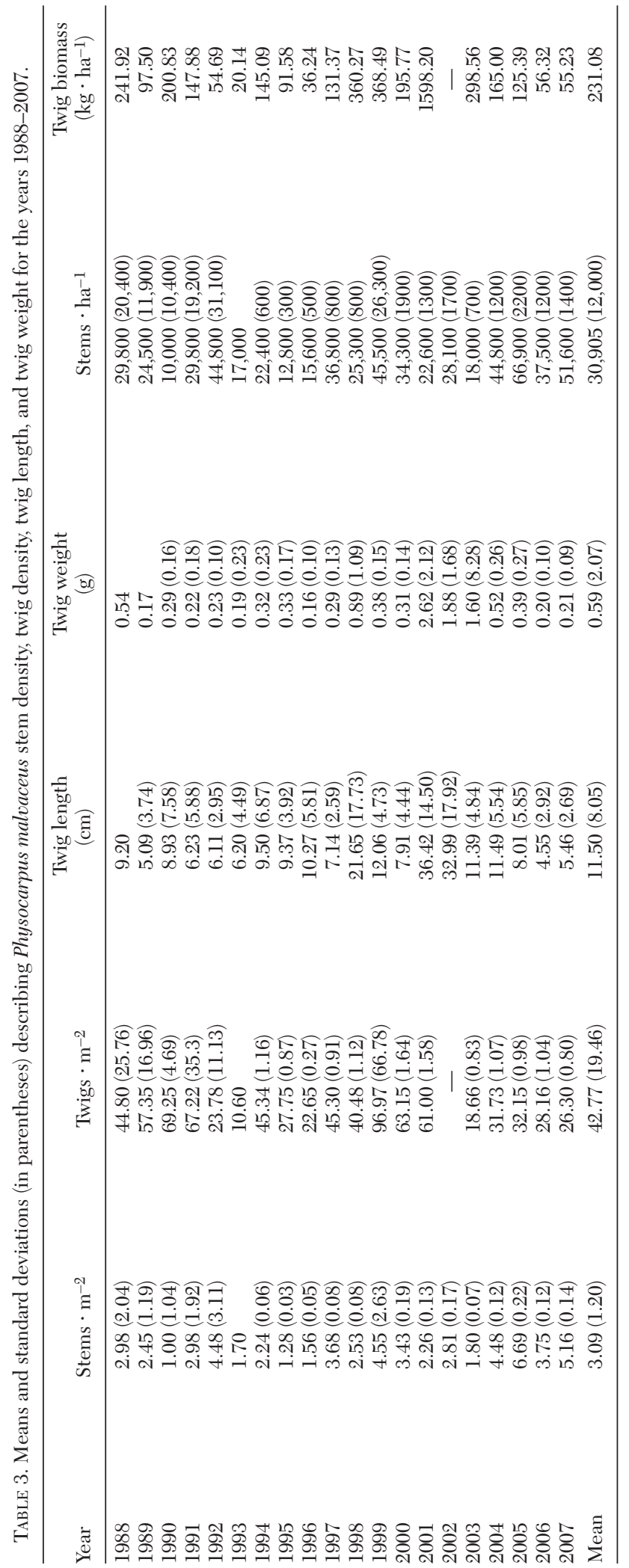




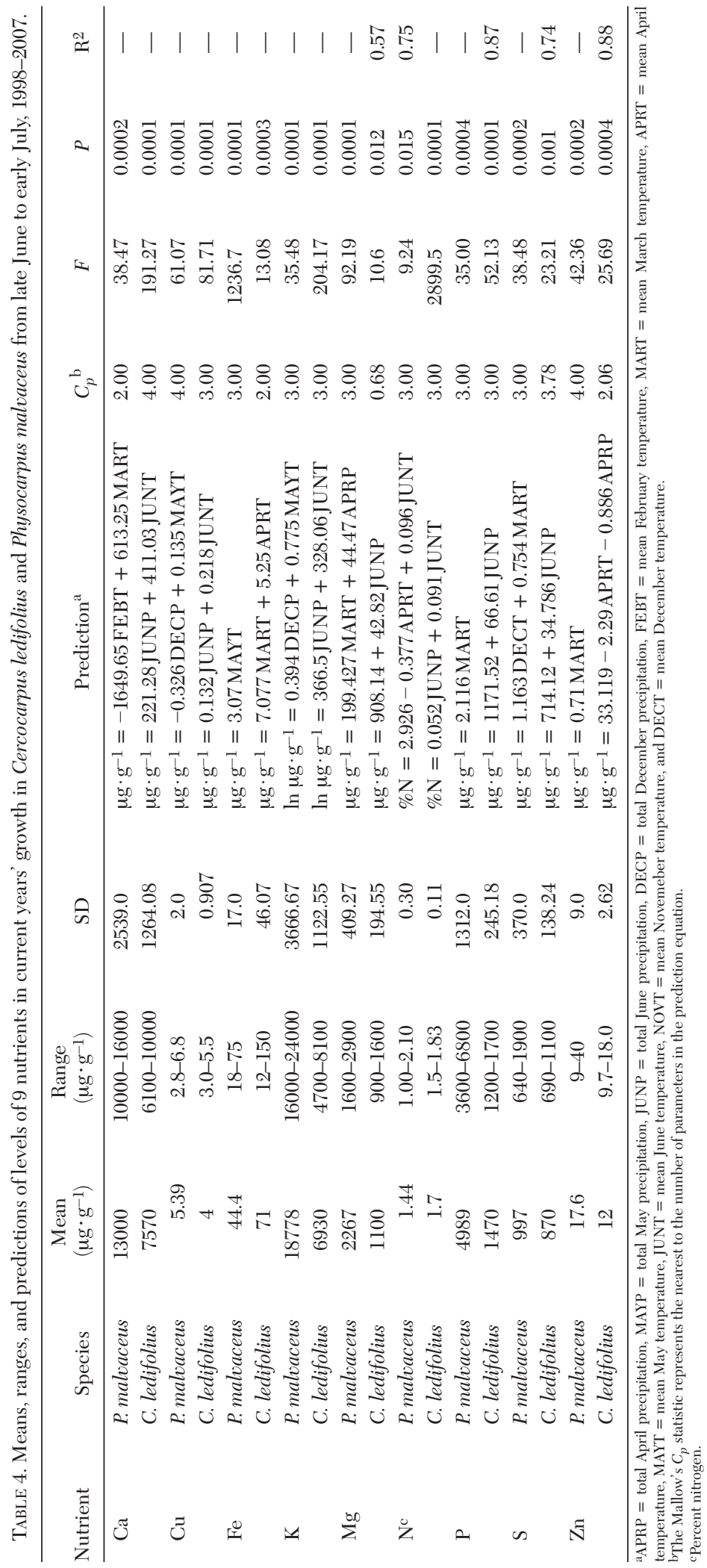




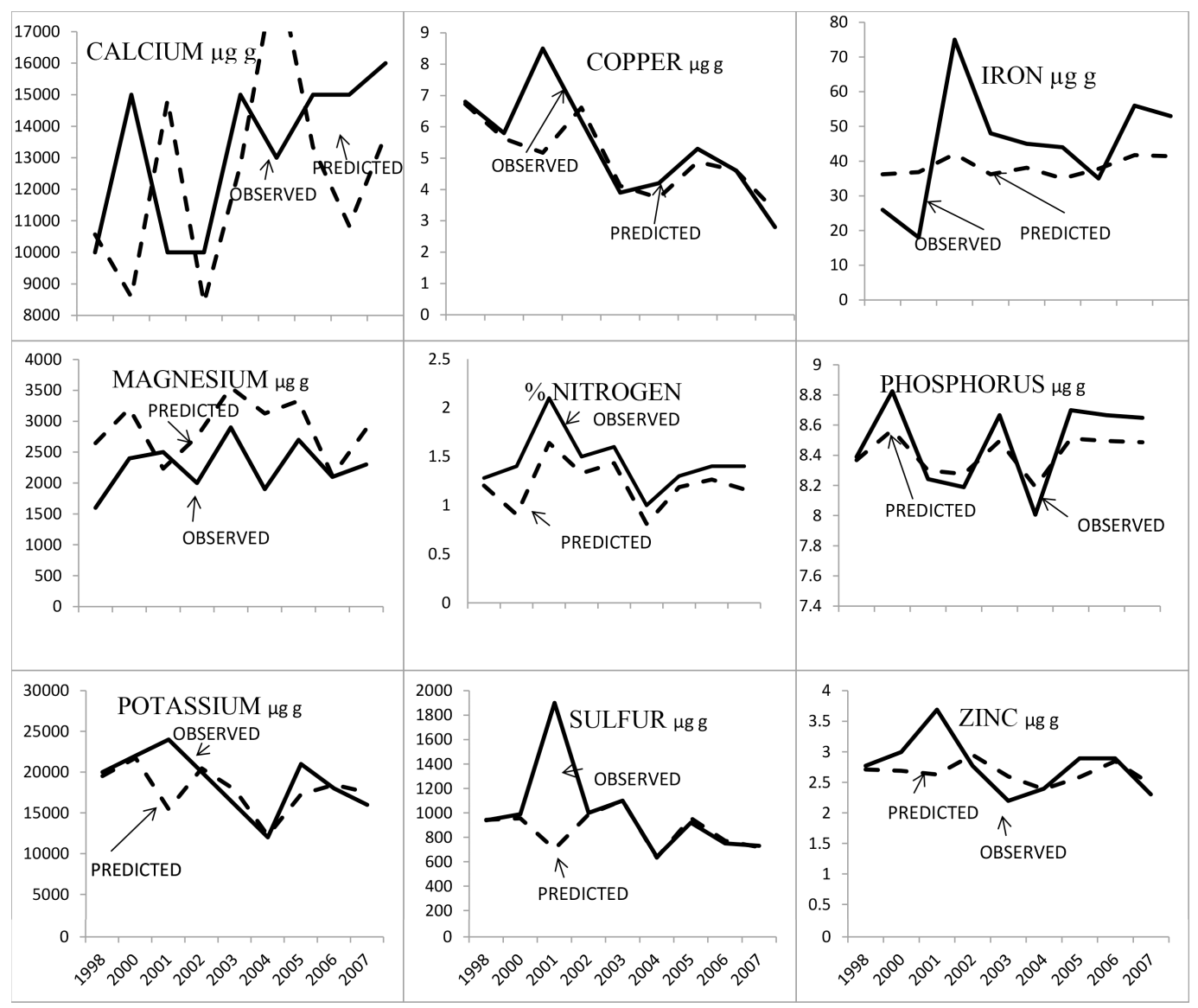

Fig. 5. Observed levels (solid line) and predicted levels (dashed line) of 9 nutrients $\left(\mu \mathrm{g} \cdot \mathrm{g}^{-1}\right)$ in Physocarpus malvaceus. Prediction equations are listed in Table 4.

whereas the levels of micronutrients $\mathrm{Fe}$ and $\mathrm{Zn}$ were lowest (Table 4). Range of variation for all nutrients was highest for P. malvaceus.

Mean monthly temperature was included in all 9 predictions of nutrient levels in P. malvaceus (Table 4). November-February temperatures were negatively correlated in $\mathrm{Ca}$ and $\mathrm{Cu}$, whereas March temperature was positively correlated with $\mathrm{Ca}, \mathrm{Mg}, \mathrm{P}, \mathrm{S}$, and Zn. AprilJune temperatures and precipitation were positively correlated with $\mathrm{Cu}, \mathrm{Fe}, \mathrm{K}, \mathrm{Mg}$, and $\mathrm{N}$.

Levels of $\mathrm{Ca}$ and $\mathrm{P}$ in P. malvaceus for 2001 and 2002 , the 2 years following the fire were within the range observed for the previous years (Fig. 5). Levels of $\mathrm{K}$ were highest the year following the fire at $24,000 \mu \mathrm{g} \cdot \mathrm{g}^{-1}$. Prediction equations for $\mathrm{Ca}$ were negative for February and positive for March temperatures (Fig. 5, Table 4). March mean temperature and April precipitation predicted levels of $\mathrm{Mg}$ in $P$. malvaceus with no apparent responses attributable to the fire (Table 4, Fig. 5). The highest value of $\mathrm{S}$ occurred the year after the fire in P. malvaceus and was 1.8 times (1600 $\mu g \cdot g^{-1}$ ) the mean for the 10-year period (Fig. 5).

Range of variation in $\mathrm{Fe}$ was highest in $C$. ledifolius (Table 4, Fig. 6), whereas ranges of variation in the other 8 nutrients were highest in P. malvaceus. Levels of $\mathrm{Cu}$ in P. malvaceus the year following the fire were 1.7 times the mean for the other 9 years (Fig. 5). Levels of Fe in P. malvaceus in 2004 were 1.85 times the values for the other 9 years (Fig. 5). High variation in $\mathrm{Zn}$ was found in C. ledifolius (Fig. 6). Levels of $\mathrm{Zn}$ in P. malvaceus for the year following the fire were 2.7 times greater than the mean for the 1998-2000 plus 2003-2007 period (Table 4, Fig. 5). 


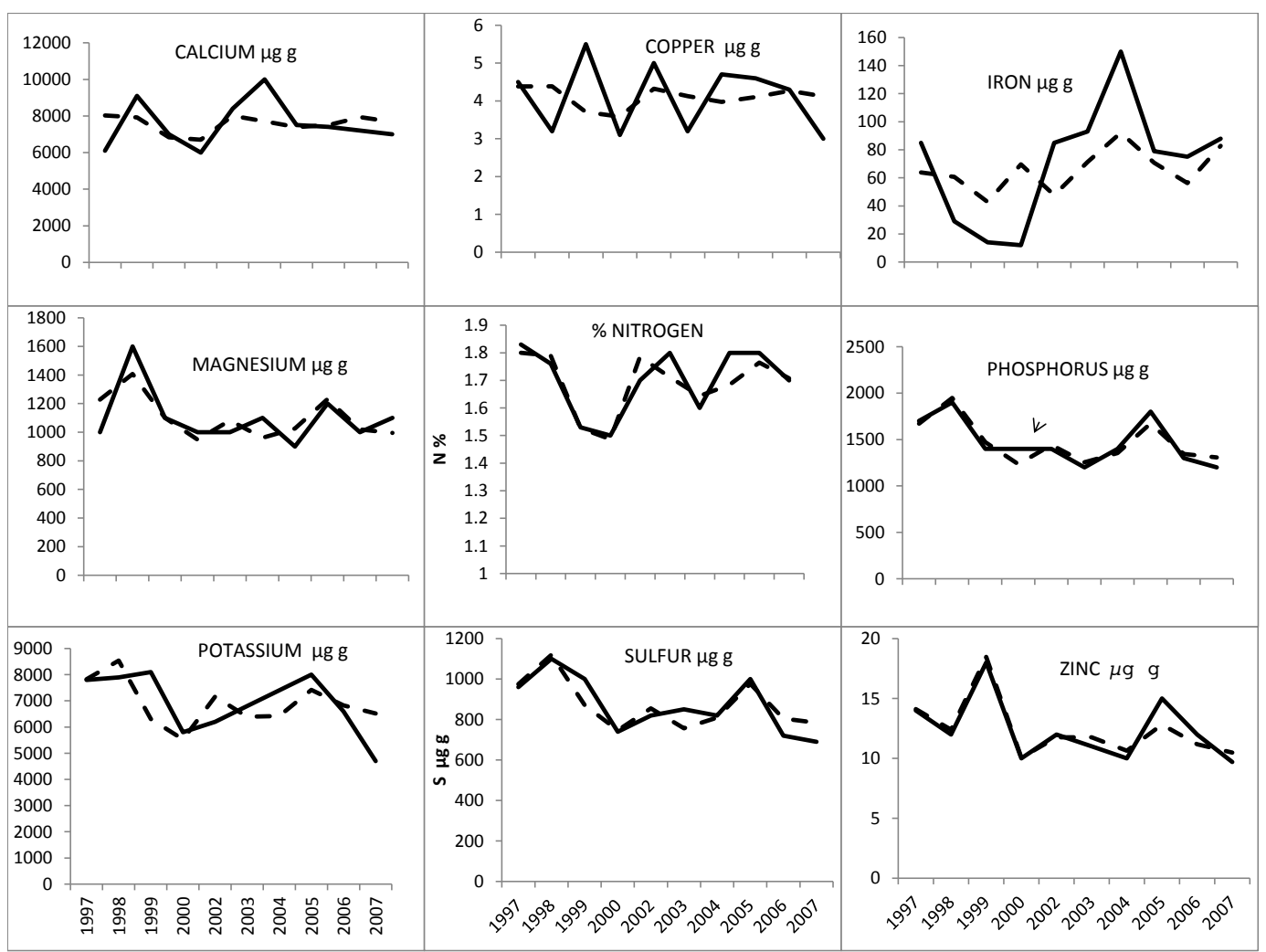

Fig. 6. Observed levels (solid line) and predicted levels (dashed line) of 9 nutrients $\left(\mu \mathrm{g} \cdot \mathrm{g}^{-1}\right)$ in Cercocarpus ledifolius. The prediction equations are listed in Table 4.

Cercocarpus ledifolius had the highest $\mathrm{N}$ values (Table 4, Fig 6). Predictions of N content in P. malvaceus included April and June temperatures (Table 4). The highest value for $\mathrm{N}$ in P. malvaceus (2.1\%) occurred in 2001, the year following the fire, 1.54 times the mean value of $1.36 \%$ for the $1998-2000$ plus 2003 2007 period. The value for 2002 (1.7\%) fell between the values for the 2 periods.

\section{Discussion}

Physocarpus malvaceus responded to the fire with increases in nutrients and weight of current year's growth similar to the response reported by Merrill et al. (1982). Warm Januaries and lower December precipitation values produced higher weights of $P$. malvaceus, whereas increased October temperatures increased weights of $C$. ledifolius. Physocarpus malvaceus was apparently metabolizing in midwinter when conditions allowed, whereas
C. ledifolius was responding to growing seasons in the previous year that lasted into fall.

Total biomass of current year's production would also include growth of existing stems and roots as well as twigs. Also, P. malvaceus had not produced flowering stalks, which started later in this area than the latest startdate reported by Schmidt and Lotan (1980) for northern Idaho and western Montana. However, twig growth was estimated to be completed for the year. Nevertheless, this work represents minimum estimates of total productivity for each year by excluding growth on existing roots and stems, and flowering stalks.

Shrub communities pose difficult sampling problems because they are highly variable (Pechanec and Stewart 1941, Rutherford 1979). Collection of density data using direct counts in plots is time consuming and tedious. Generally, plot-based techniques have proven better for sampling than plotless sampling 
methods, and a prohibitive number of samples may be required to detect density differences in plotless samples (Lyon 1968). For long-term data sets, observer differences undoubtedly contribute to variation, especially for estimations of twig density, which are especially tedious. High variance in a $P$. tridentata stand in western Montana led Lyon (1968) to conclude that reliable estimation of density required unreasonably high sampling levels regardless of method used in that stand, a conclusion that confirmed earlier work in sagebrush-grass steppe by Pechanec and Stewart (1941). Density of plants in that stand was $0.122 \mathrm{~m}^{-2}$, as compared to $0.319 \mathrm{~m}^{-2}$ estimated in the study stand. Densities in an Artemisia tridentata-Purshia tridentata stand in southern Oregon ranged from 0.75 to 1.56 $\mathrm{m}^{-2}$ (Ziegenhagen and Miller 2009), suggesting that the stand Lyon (1968) sampled was low density and highly variable. Oldemeyer and Regelin (1980) recommended a $5-\mathrm{m}^{-2}$ quadrat for sampling shrub density in Alaska as being practical for field use in tall shrub communities.

Twig and stem density estimations were more variable in the $C$. ledifolius stand than in the P. malvaceus stand. The more even distribution and higher density of plants in the P. malvaceus stand likely contributed to the difference in quality of the estimates. This analysis suggests that in shrub stands composed of sprouting, rhizomatous species such as the $P$. malvaceus stand, density estimations may be more reliable than for more heterogeneous stands. Regardless, estimations provided here apply for the plot size and number sampled and for the individual stands that were studied, and may not be comparable to different sampling procedures or other stands.

Estimates of twig weight from length and basal diameter provide accurate results (Basile and Hutchings 1966, Telfer 1969, Lyon 1970, Peek et al. 1971). In this study, estimations are considered more reliable than the density estimates.

Controlled experimentation involving replicated sites will provide the best understanding of how predictions of nutrient levels are related to temperature and precipitation. While comparisons can be made with other sites in the field, cause-effect relationships will likely require controlled study in experimental plots. Nutrient uptake is influenced by seasonal pat- terns of nutrient availability in soil, soil temperature, means of transport from soil to roots, soil microorganisms, indirect effects of light on photosynthesis, effect of nutrients on absorption of one another, root turnover rates, rates of chemical reactions of the different nutrients, and selection pressures, among other things (Sutcliff 1962, Aerts and Chapin 2000, Arihara and Srinivasan 2001, Gutschick and Pushnik 2005, Pregitzer and King 2005). Regardless, predictions of nutrient uptake and content in changing environments can be useful for investigations of climatic changes (Gutschick and Pushnik 2005).

Nutrient content of $C$. ledifolius was best predicted with spring temperatures and precipitation, whereas biomass predictions used October mean monthly temperature. This suggests that warm fall seasons allow this species, which retains its leaves over winter, to extend metabolic processes including $\mathrm{N}$ fixation later into the fall and carry over to the next growing season (Davis and Brotherson 1991). The high twig weight for C. ledifolius for 1995 compared to the predicted value also suggests that growing conditions prior to the previous October affect weights as well. N levels are similar to those reported by Dietz et al. (1962) for Cercocarpus montanus Raf. Heights and twig biomass in the C. ledifolius/P. spicata stand were twice those that Mackie (1973) reported from Montana sites. Biomass estimates for C. ledifolius were much lower than the $+150 \mathrm{~kg} \cdot \mathrm{ha}^{-1}$ reported for $C$. montanus in Colorado by Medin (1960). Soil depth and clay content positively influenced production on the Colorado sites, and soils in this study were much more productive than the nutrient-poor soils typically occupied by C. ledifolius (Davis and Brotherson 1991).

Clarke (2002) reported that rocky outcrops have the lowest proportion of nonresprouting species compared with more mesic sites in eastern Australia. Cercocarpus ledifolius, the nonresprouter, likely evolved and currently occurs in areas where disturbances are less frequent than areas occupied by $P$. malvaceus (Bond and Midgley 2003). The range of variation in twig biomass for P. malvaceus was 20.4 over the 13 year period prior to the fire. This contrasts with the range of variation in biomass for C. ledifolius of 8.8 for the 20-year period on the unburned site. No evidence of seedling establishment by $P$. malvaceus was 
observed following the fire, and all new growth occurred as resprouts. This contrasted with observations on the C. ledifolius stand where seedling establishment was observed. Cercocarpus ledifolius is also a taller plant than $P$. malvaceus, supporting arguments that species that reseed following disturbance will be taller than sprouting species (Midgley 1996).

Climatic change is predicted to alter plant community composition, but changes in productivity may occur prior to successional trends. Under contemporary disturbance regimes, which include wildfire, shrubs with different adaptations may shift in occurrence but remain present through time, given no change in climate. However if climatic changes increase frequency and severity of disturbances, then species composition should change more rapidly. Species that resprout following higher-frequency disturbances may benefit initially over those that depend on seedling establishment for their continued presence. However, if fire frequency dramatically increases, shrub species that evolved in more arid and warmer climates with lower disturbance frequencies, which would include species that depend upon seedling establishment, may eventually benefit over species that resprout.

\section{Conclusions}

Production and nutrient content varied significantly between species and over the study period. The predictions and ranges of production and nutrient content apply for the range of temperatures and monthly precipitation that occurred during the investigation and to the sites that were studied. If changes in these values or the predictions appear in subsequent evaluations, then consideration should be given to changes in precipitation and temperature patterns as the reason. Whether sprouting shrubs or seeding shrubs would benefit from increased atmospheric $\mathrm{CO}_{2}$ content or increased wildfire frequency will need continued investigation. Though the sprouting shrubs immediately responded to the fire, the nonsprouters that seed in pulses and tolerate higher temperatures and less moisture may take longer to respond under currently observed conditions; however, they could ultimately gain dominance over sprouters. Longterm investigations will be needed to evaluate specific responses to environmental change.

\section{ACKNOWLEDGMENTS}

I thank H. Akenson, J. Akenson, R. Riggs, and J. Yeo for providing logistics, help with data collection, and encouragement of this work. O. Garton and K. Steinhorst provided advice with the statistical analysis. Students of the College of Natural Resources who participated in the data collection are gratefully acknowledged for their efforts. Research was funded by the College of Natural Resources at the University of Idaho and the DeVleig Foundation.

\section{Literature Cited}

AERTS, R., AND F.S. Chapin III. 2000. The mineral nutrition of wild plants revisited: a re-evaluation of processes and patterns. Advances in Ecological Research 30:1-67.

Altwegg, B., H.M. DeKlerk, and G.G. Midgley. 2015. Fire-mediated disruptive selection can explain the reseeder-resprouter dichotomy in Mediterraneantype vegetation. Oecologia 177:367-377.

Arihara, J., and A. Srinivasan. 2001. Significance of nutrient uptake mechanisms in cropping systems. Pages 487-503 in A.E. Noriharu, J. Arihara, K. Okada, and A. Srinivasan, editors, Plant nutrient acquisition, new perspectives. Springer-Verlag, Tokyo.

Basile, J.C., AND S.S. Hutchings. 1966. Twig diameterlength-weight relations of bitterbrush. Journal of Range Management 19:34-38.

Bellingham, P.J., AND A.D. Sparrow. 2000. Resprouting as a life history strategy in woody plant communities. Oikos 89:409-416.

Bond, J.G., J.D. Kauffman, D.A. Miller, And R. Venkatakrishnam. 1978. Geologic map of Idaho. Idaho Bureau of Mines and Geology, Moscow, ID.

Bond, W.J., And J.J. Midgely. 2003. The evolutionary ecology of sprouting in woody plants. International Journal of Plant Science 164 (S3):S103-S114.

Clarke, P.J. 2002. Habitat islands in fire-prone vegetation: do landscape features influence community composition? Journal of Biogeography 29:677-684.

DAVIS, J.N., AND J.D. BRotherson. 1991. Ecological relationships of curlleaf mountain-mahogany (Cercocarpus ledifolius Nutt.) communities in Utah and implications for management. Great Basin Naturalist 51:153-166

DEALY, J.E. 1978. Autecology of curlleaf mountain-mahogany (Cercocarpus ledifolius). Pages 398-400 in Proceedings of the First International Rangeland Congress.

Dietz, D.R., R.H. Udall, and L.E. Yeager. 1962. Chemical composition and digestibility by mule deer of selected forage species, Cache La Poudre Range, Colorado. Colorado Game and Fish Department Technical Publication 14. 89 pp.

Gilmour, S.G. 1996. The interpretation of Mallows's $C_{p^{-}}$ statistic. Statistician 45:49-56.

Gutschick, V.P., AND J.C. Pushnik. 2005. Internal regulation of nutrient uptake by relative growth rate and nutrient-use efficiency. Pages 62-88 in H. BassiriRad, editor, Nutrient acquisition by plants: an ecological 
perspective. Springer-Verlag, Berlin. dx.doi.org/ 10.1046/j.1365-2699.2002.00716.x

Hitcheock, C.L., AND A. Cronquist. 1996. Flora of the Pacific Northwest. University of Washington Press, Seattle, WA. $730 \mathrm{pp}$.

LYON, L.J. 1968. An evaluation of density sampling methods in a shrub community. Journal of Range Management 21:16-20.

LYON, L.J. 1970. Length- and weight-diameter relations of serviceberry twigs. Journal of Wildlife Management 34:456-460.

MaCKIE, R.J. 1973. Evaluation of range survey methods, concepts and criteria: responses of four browse species to protection on big game winter ranges in western Montana. Project W-120-R-3, Job Progress Report, Montana Department of Fish, Wildlife, and Parks, Helena, MT. 30 pp.

MaLlows, C.L. 1973. Some comments on $C_{p}$. Technometrics 15:661-673.

Manea, A., And M.R. Leishman. 2015. Competitive interactions between established grasses and woody plant seedlings under elevated $\mathrm{CO}_{2}$ levels are mediated by soil water availability. Oecologia 177:499-506.

Matthews, J.V., Jr., and L.E. Ovenden. 1990. Late Tertiary plant macrofossils from localities in Arctic/Subarctic North America: a review of the data. Arctic 43:339-344.

Mayeux, H.S., H.B. Johnson, and H.W. Polley. 1991. Global change and vegetation dynamics. Chapter 7 in L.F. James, J.O. Evans, M.H. Ralphs, and R.D. Child, editors, Noxious range weeds. Westview Press, Boulder, CO.

McArthur, E.D., M.C. Stutz, and S.C. Sanderson. 1983. Taxonomy, distribution, and cytogenetics of Purshia, Cowania, and Fallugia (Rosoidea, Rosacea). Pages 4-24 in Proceedings: research and management of bitterbrush and cliffrose in western North America. USDA Forest Service INT-152.

Medin, D.E. 1960. Physical site factors influencing annual production of true mountain mahogany, Cercocarpus montanus. Ecology 41:454-460.

Merrill, E.H., H.F. Mayland, and J.M. Peek. 1982. Shrub responses after fire in an Idaho ponderosa pine community. Journal of Wildlife Management 46:496-502.

Midgley, J.J. 1996. Why the world's vegetation is not totally dominated by resprouting plants; because resprouters are shorter than reseeders. Ecography 19:92-95.

NowaK, C.L., R.S. NowaK, R.J. Tausch, and P.E. WigAND. 1994. Tree and shrub dynamics in northwestern Great Basin woodland and shrub steppe during the late-Pleistocene and Holocene. American Journal of Botany 81:265-277.

Oldemeyer, J.L., AND W. Regelin. 1980. Comparison of 9 methods for estimating density of shrubs and saplings in Alaska. Journal of Wildlife Management 44:662-666.

Pausas, J.G. 2001. Resprouting vs seeding-a Mediterranean perspective. Oikos 94:193-194.

Pechanec, J.F., and G. STewart. 1941. Sagebrush-grass range sampling studies: variability of native vegetation and sampling error. Journal of the American Society of Agronomy 33:1057-1070.
Peek, J.M., L.W. Krefting, and J.C. Tappeiner III. 1971. Variation in twig diameter-weight relationships in northern Minnesota. Journal of Wildlife Management 35:501-507.

Peek, J.M., J.J. Yeo, W.O. Hickey, J.L. Lauer, and J.C. ClaAR. 2005. Shrub-steppe vegetation of the East Fork and Middle Fork of the Salmon River Drainages. Idaho Forest, Wildlife, and Range Experiment Station Bulletin 82.78 pp.

Polley, H.W., H.B. Johnson, and H.S. Mayeux. 1994. Increasing $\mathrm{CO}_{2}$ : comparative responses of the $\mathrm{C}_{4}$ grass Schizachyrium and grassland invader Prosopis. Ecology 75:976-988.

Pregitzer, K.S., AND J.S. King. 2005. Effects of soil temperature on nutrient uptake. Pages 275-310 in $\mathrm{H}$. BassiriRad, editor, Nutrient acquisition by plants: an ecological perspective. Springer-Verlag, Berlin.

Russell, S.K., AND E.W. SCHUPP. 1998. Effects of microhabitat patchiness on patterns of seed dispersal and seed predation of Cercocarpus ledifolius (Rosaceae). Oikos 81:434-443.

Rutherford, M.C. 1979. Plant-based techniques for determining available browse and browse utilization: a review. Botanical Review 45:203-228.

SAS Institute, InC. 2008. SAS, version 9.2. Cary, NC.

SChEldT, R.S., AND E.W. Tisdale. 1970. Ecology and utilization of curl-leaf mountain mahogany in Idaho. University of Idaho Forest Wildlife and Range Experiment Station Note $15.2 \mathrm{pp}$.

SChMidT, W.C., AND J.R. Lotan. 1980. Phenology of common forest flora of the northern Rockies 1928-1937. Research Paper INT-259, USDA Forest Service, Ogden, UT. $20 \mathrm{pp}$

Schultz, B.W., R.J. Tausch, and P.T. Tueller. 1996. Spatial relationships among young Cercoarpus ledifolius (curlleaf mountain mahogany). Great Basin Naturalist 56:261-266.

Steele, R., R.D. Pfister, R.A. Ryker, and J.A. Kittams. 1981. Forest communities of central Idaho. General Technical Report INT-114, USDA Forest Service, Intermountain Forest and Range Experiment Station, Ogden, UT.

Sutcliff, J.F., P.F. WAREIng, AND A.W. Galston. 1962. Mineral salts absorption in plants. Pergamon Press, NY.

Telfer, E.S. 1969. Twig weight-diameter relationships for browse species. Journal of Wildlife Management 33:917-921.

Western Regional Climate Center. 2011. Taylor Ranch Idaho, 1981-2010 monthly climate summary. Desert Research Institute, Reno, NV. http://www.wrcc.dri.edu

WING, S.L. 1987. Eocene and Oligocene floras and vegetation of the Rocky Mountains. Annals of the Missouri Botannical Garden 74:748-784.

Wolfe, J.A., AND W.C. WeHr. 1991. Significance of the Eocene fossil plants at Republic, Washington. Washington Geology 19(3):18-24.

Ziegenhagen, L.L., AND R.F. Miller. 2009. Postfire recovery of two shrubs in the interiors of large burns in the Intermountain West, USA. Western North American Naturalist 69:195-205.

Received 3 November 2014 Accepted 15 June 2015 